\section{Zimbabwe's Inheritance}

edited by Colin Stoneman, University of Zimbabue

This pioneering study presents the first comprehensive analysis of Zimbabwe's political, social and economic parameters as the country and its leaders cope with the problems and ramifications of her newly-independent status. Based on the most recent statistics and information available, the book provides a concise examination of the political forces, institutions and conflicts inherited by the new leadership and of the tensions produced by the existing social structure.

March $1982 \quad$ ISBN 0-312-89883-5 266 pages, maps $\$ 25.00$

Written by a member of the Constitutional Drafting Committee, this comprehensive analysis of the 1979 Constitution and its workings offers illuminating insights into the general principles of the Nigerian presidential system of government. The book explores the nature of the Constitution, federalism and the division of power and reviews the major components of a presidential system.

September 1982

ISBN 0-312-64032-3

575 pages

$\$ 45.00$

The Struggle for Africa Conflict of the Great Powers

Gerard Chaliand
This piercing examination explores in-depth the background to East-West rivalry in Africa, its extent, its causes, and the likely shape of future conflict. The author offers thorough case studies in three key areas of dispute: Southern Africa, the Horn, and the Western Sahara and pays particular attention to the presence of Cuban troops and Soviet military personnel stationed in Angola and Ethiopia.

September $1982 \quad$ ISBN 0-312-76868-0 approx. 140 pages $\$ 16.95$

To order these books at $20 \%$ discount, please send your check or institutional purchase order to: 


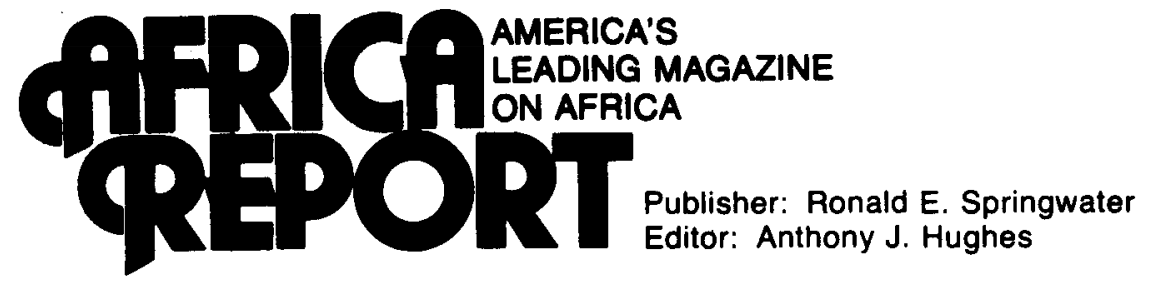

A Publication of the African-American Institute

A nonpartisan newsmagazine of African affairs featuring in-depth studies, reports from correspondents, and current news analyses from the whole of Africa. Africa Report has an impressive track record of forecasting major changes and developments in African affairs and is considered essential reading for those whose personal or professional interests require them to keep abreast of what is happening in the fast-changing continent.

Regular features include:

African Update: Detailed reports on events on a region-by-region and country-by-country basis, culled from 250 publications and radio stations in Africa and around the world.

In Washington: Regular analyses of the United States/African relations, with special emphasis on how United States policy is formulated.

Country Profiles: Africa Report specializes in expert descriptions of developments within and between African states. So when dramatic developments take place, readers have an insider's advance understanding.

Overviews: Economic developments, business affairs, investment opportunities, education, and religion.

\section{Book Reviews}

Recent issues include:

Nigeria Shagari's First Two Years By Larry Diamond

Parls Newsletter Mitterand's Africa Policies By Alex Rondos

Tourism Tanzania's Controversial Industry By Peter Marshall

In Washington Reagan's Private Sector Thrust By Susan Gilpin

Published six times a year. Founded 1957.

Subscription rates: Individuals $\$ 18 / 1$ yr. $\$ 34 / 2$ yr. $\$ 48 / 3$ yr.: Institutions $\$ 24,1$ yr. $\$ 44 / 2$ yr. \$62/3 yr.: Outside the U.S.A.: Add $\$ 3.00$ /yr.: Airmail: Add $\$ 24 /$ yr.: Single copies $\$ 3.50$. ISSN 0001-9836.

Please address inquiries and orders to:
Transaction Periodicals Consortium Department TA 2000

Rutgers-The State University

New Brunswick. NJ 08903 


\section{ON THE \\ CUTTING EDGE \\ OF HISTORICAL RESEARCH}

Methods developed in African history are just beginning to be used by historians of other world areas.

Those methods-including linguistics, oral traditions, textual evaluation, comparative historical and historiographical research-are the major concern of African historians and of historians everywhere.

HISTORY IN AFRICA is an essential companion to any contemporary historical bookshelf.

$\$ 15$ per volume, plus postage and handling.

HISTORY IN AFRICA: A JOURNAL OF METHOD Professor David Henige, Editor

An annual publication of the African Studies Association, 255 Kinsey Hall, UCLA, 405 Hilgard Avenue, Los Angeles, CA 90024, (213) 206-8011. 


\section{AFRICAN STUDIES ASSOCIATION}

THE AFRICAN STUDIES ASSOCIATION was organized in 1957 as a nonprofit membership corporation to bring together persons with a scholarly and professional interest in Africa, to provide useful services to the Africanist community, and to publish and distribute appropriate scholarly and informational materials. Membership is open to individuals and institutions.

AN ANNUAL MEetimg in the Fall provides an occasion for panels, plenary sessions and discussion groups, exhibits and films. Participants from America, ifrica and Europe gather for this Meeting which is held in different regions of the U.S. each year, in cooperation with major colleges, universities and museums, and under the program direction of a distinguished Africanist. The annual business meeting of the members of the ASA takes place at that time.

\section{MEMBERS RECEIVE THREE REQULAR PUBLIGATIONS:}

AFRICAN STUDIES REVIEW: Prints review articles and essays of scholarly and bibliographical substance. Incorporates the former ASA REVIEW OF BOOKS. maintaining its critical evaluation of significant Africanist publications. Edited by R. Hunt Davis, Jr. and Melvin E. Page.

ISSUE: A JOURMAL OF OPINION: Presents provocative and timely comment on critical developments in Africa and African studies. Guest edited by distinguished scholars and professionals. Recent editions have focussed on the Second Republic of Nigeria (C.S. Whitaker) and the Reconstruction of Zimbabwe (L. Suransky and A. Mazrui).

ASA NEWS: Reports current and future activities of the Association, bibliographical and news notes, employment notices, significant correspondence and announcements of concern to the world community of Africanists.

DUES: IUSTITUTIONS: \$48 domestic; $\$ 55$ overseas surface; $\$ 90$ overseas aırmail

DUES: INDIVIDUALS: $\$ 40$ regular and sustaining members earning over $\$ 20,000$ per year, $\$ 30$ regular and sustaining members earning less than $\$ 20,000$ per year, $\$ 15$ student. retired and unemployed ( 3 year limit); $\$ 80$ arrmail (for addresses outside North America). Sustaining membership is available upen request after three years of consecutive regular membership. Sustaıning members receive complimentary registration at annual meetings and can stand for election.
ADDRESS:

Executive Secretary

African Studies Association

255 Kinsey Hall

UCLA

405 Hilgard Avenue

Los Angeles, California 90024

(213) 206-8011 
Return Requested:

AFRICAN STUDIES ASSOCIATION

255 Kinsey Hall

University of California-Los Angeles

405 Hilgard Avenue

Los Angeles, California 90024

Non-Profit

U.S. Postage

PAID

Ann Arbor, Mich.

Permit No. 195 